\title{
Morpho-Chemical Composition Characteristics of Juniperus and Pistacia Genera as Bio-Indicator of Construction Dust in Al- Jabal Al- Akhder-Libya
}

\author{
Rania F. M. Ali ${ }^{*}$ and Ahlam K. Alaila
}

Botany Department, Faculty of Science, Omar AL-Mukhtar University, Libya

DOI:10.36348/SJLS.2019.v04i08.001 | Received: 19.08.2019| Accepted: 26.08.2019| Published: 23.09.2019

*Corresponding author: Rania F. M. Ali

\section{Abstract}

This study was designed to find out effect of random construction on morphological and chemical composition characteristics of Juniperus and Pistacia. Both species of the plant were collected from two different areas in AL-Gabal AL-Akhder. First area was exposed to pollution from random construction that causing dust-contaminated cement to the plants, while the second area was not contaminated. The plants which are affected by building materials and grazing have smaller wrinkled yellow to grey leaves, while the fruits look smaller in size compared to same species from clean area. Our results shown that the both species of plants (Juniperus phoenicea and Pistacia lentiscus) were get difference in amount of mineral and the phenolic contents. The levels $\mathrm{K}$ and $\mathrm{Cu}$ were significantly decreased in J. phoenicea 1 (from polluted area) compared to J. phoenicea 2 (from clean area), while the level of Ca significantly increased. Rest levels of minerals were found similar in J. phoenicea 1 and J. phoenicea 2. In another species level of $\mathrm{Na}, \mathrm{Fe}$ and $\mathrm{Ni}$ were decreased significantly in polluted species (P. lentiscus 1 ) compared to clean species (P.lentiscus 2 ), while the levels of $\mathrm{K}$ and $\mathrm{Ca}$ was significantly increased in $P$. lentiscus 1 which collected from polluted area. Levels of alkaloids, coumarins, essential oil, flavonoids, glycosides, phenolic compounds, saponins, sterols (triterpens) and tannins were found have similar pattern when compared J. phoenicea 1 with P. lentiscus 1 and J. phoenicea 2 with P. lentiscus 2. These results from Juniperus and Pistacia species might reflected the deteriorate effects of construction dust air pollutants, both species recommend their using as bio indicators as well as folk medicine.

Keywords: Construction dust, morphology, chemical composition, Juniperus, Pistacia and Libya.

Copyright @ 2019: This is an open-access article distributed under the terms of the Creative Commons Attribution license which permits unrestricted use, distribution, and reproduction in any medium for non-commercial use (NonCommercial, or CC-BY-NC) provided the original author and source are credited.

\section{INTRODUCTION}

The dust pollution has caused many problems relating to the environment, health, hygiene, economy and aesthetics. Many physiological and biochemical responses of plants to cement dust or construction dust pollution have been observed [1-4], epiphytic lichens and bryophytes [5]. During the last 7 years (20112017), the growth in urban population and extensive development activities have increased levels of air pollution in the Libya that cause harmful effects to humans, animals and plants [6]. In Libya there are about 1,825 vascular plant species, of which 134 are endemic. About 450 species are reported to be of medicinal value [7]. More than 100 species are extensively used by local people in folk medicine drinks, or chewed fresh or dry. They are used to cure dermal diseases, viral or bacterial infections, insect or animal bites, burns and sometimes to treat hair problems. Al-Jabel Al-Akhdar represents a rich coverage of natural vegetation in Libya. The most dominating families, in terms of distribution, are East Libya. From these natural vegetation, cupressaceae family of c.16 genera and 140 species, mainly in temperate. And subtropical regions of the northern hemisphere, some in tropical mountains. Represented here by 3 genera and 4 species. The family Cupressaceae monoecious or dioecious, resinous evergreen trees or shrubs [8,9]. Also, anacardiaceae family, with c.60 genera and nearly 600 species, mostly in tropical regions but some subtropical or in temp. Europe, Asia and America; represented here by 3 genera and 6 species. Some are known from cultivation only. Family Anacardiaceae trees or shrubs (rarely climhers) bark resinous [8, 9]. In recent years, it has been observed an increasing interest for biological properties of medicinal plants, in order to identify and evaluate their therapeutic potential and also to identify the major bioactive compounds and possible 
synergisms $[10,11]$. Chemical composition also is generally used to differentiate between different plant $\mathrm{sp}$; for example protein patterns of soya beans were found to be considerably different from those of other species [12]. Plant physiological parameters have been used as bio-indicators of urban habitat quality. For example, highly alkaline dust like cement visibly injures plant leaves; even chemically inert dust physically affects photosynthesis and transpiration when it accumulates on leaf surfaces. Covering and plugging of stomata [13], shading [14, 15], increasing leaf temperature $[16,17]$ and removal of cuticular wax $[18,19]$ had been used to characterize local air pollution [20]. Less attention has been given to morphological and anatomical parameters of plants as indicators of long-term responses to changing (urban) habitat quality, although parameters as specific leaf area, stomatal density and pore surface were recognized to vary depending on microclimatic conditions [21]. Moreover, sampling and analysis of these parameters are relatively easy and inexpensive. Trees act as a sink for air pollutants and thus reduce their concentration in the air especially in urban environments [22-24]. Dust interception capacity of plants depends on their surface geometry, phyllotaxy, and leaf external characteristics such as hairs, cuticle, leaf shape and size, texture, length of petioles, and canopy of trees etc., weather conditions and direction and speed of wind and anthropogenic activities [25-27]. In Libya, less attention has been given to morphological with chemical composition characteristics parameters of plants as indicators of long-term responses to changing habitat quality. Juniperus phoenicea and Pistacia lentiscus are plants used by the local residents in different purposes. Therefore, this study was designed to find out Morphochemical composition characteristics of Juniperus and Pistacia species as Bio-indicator of construction dust in AL Jabal AL Akhder-Libya.

\section{MATERIALS AND METHODS Site Description}

The study was carried out at two sites located in AL Gabal AL Akhder. Both species Juniperus phoenicea and Pistacia lentiscus were collected from two different areas (distance between two location was about $20 \mathrm{Km}$ ). First area was exposed to pollution from random construction that causing dust-contaminated to the plants and these pollution started 7-10 years ago. While the second area was not contaminated. Both locations get similar geographic distribution. Arial parts of Juniperus phoenicea and Pistacia lentiscus were collected from March to October 2018 and then dried in the shade for 10 days. The identified specimens were compared with already identified Herbarium Sylphum of the Botany Department

\section{Species Description}

Habits, duration of life, type of stem/leaves, inflorescence and type of fruit were briefly described.
The materials examined were documented with reference to collector names, and their numbers, dates, places of collection.

\section{Determination of Minerals}

The plants were carefully and thoroughly cleaned, blotted dry between absorbing paper and their dry weights were measured after oven drying at $70^{\circ} \mathrm{C}$ for $72 \mathrm{~h}$. Oven dry samples of plants were finely ground and assayed for mineral ion content by the wet digestion method [28]. Minerals (K, Ca, Na, Ni, Fe, and $\mathrm{Cu}$ ) were determined using an atomic absorption spectrophotometer (Perkin-Elmer, 2380) and expressed on the basis of dry weight. The extract obtained was subjected for assaying $\mathrm{K}$ and $\mathrm{Ca}$ concentrations using flame photometer (CORNNG 400).

\section{Phytochemical Analysis of the Plant Extracts}

The extracts were subjected to phytochemical tests for alkaloids, coumarins, essential oil, flavonoids, glycosides, phenolic compounds, saponins, sterols (triterpens) and tannins in order to know the nature of phyto constituents present in them according to the methods of [29].

\section{Statistical Analysis}

Statistical analysis was performed using a computer run program (Minitab software). One way ANOVA followed by Turkey's test was performed to show the statistical significance among the means of the groups. Results were expressed as mean \pm Standard Division (SD). Pvalue below 0.05 was considered to be statistically significant,

\section{RESULTS AND DISCUSSION}

Chemotaxonomy or chemical plant taxonomy may be defined as a scientific investigation of the potentialities of chemical characters for the study of problems of plant taxonomy and plant phylogeny [30]. In current study, beside on morphological description, this study was include two species:

\section{Pistacia lentiscus L.}

Ever green small tree or shrub, 1-3(-5) m tall. Leaves abruptly paripinnate; leaflets 2-4(-5)- paired, oblong, lanceolate or oblancealate obtuse, mucronulate , 1.5-3.5 (-5)× 0.6-1.5 cm, leathery ; rachis distinctly winged ; petiole glabrous. Inflorescence spike like, compact, flowers yellowish purple or purplish. Fruiting panicle short stiff; Drupe (3.5-) 5-8× 5-7 mm, globular - obovate, somewhat compressed, obliquely Apiculate. Fruit is utilized for making chewing gum, sweets, Batum oil and alcohol. Fl. March- April Vern: Baattoom ,dhorru, Buttoon [9].

\section{Juniperus phoenicea L.}

Monoecious shrubs or trees up to $8 \mathrm{~m}$ tall, Juvenile leaves needle -like, patent ,acute; Adult ones 0.5-2 mm long, scale-like ,ovate - rhombic, closely appressed ,somewhat. Obtuse, with a dorsal ,oblong 
turrowed giana .Cones irregularly globose, c.8-14 mm in diameter, blackish when young, dark red when ripe .Staminate cones terminal, sessile , erect , ovoid oblong , pale- brown,c.4 $\mathrm{mm}$ long, with rounded microsporophylls, each bearing 3-5 microspongia. Ovuiate cones $8-15 \mathrm{~mm}$ in diameter, terminal on short axillary spurs, fleshy, subglobular or ovoid, with 3-8 united megasporophylls. Seeds 3-8 free, narrowly ovoid- ellipsoid, wingless. From previous description, the plants (J. phoenicea 1 and P. lentiscus 1 ) which are affected by building materials and grazing have smaller wrinkled yellow to grey leaves, while the fruits look smaller in size compared to same species from clean area (J. phoenicea 2 and P.lentiscus 2) [8].

As for the chemical contents of the studied plants, the mineral element constituents of the studied (J. phoenicea 1 and P. letiscus 1$)$ compared to ( $J$. phoenicea 2 and P. lentiscus 2) were shown in Tables 1. In term of compression between both species, the current study was found the highest amount $\mathrm{Na}, \mathrm{Ca}$ and Fe in (P. lentiscus 1 and P. lentiscus 2 ) compared to ( $J$. phoenicea 1 and J. phoenicea 2). However, the lowest amount $\mathrm{K}$ and $\mathrm{Ni}$ in P. lentiscus 1 and P.lentiscus 1 compared to J. phoenicea 2 and J. phoenicea 2 . Usually the absorption of $\mathrm{K}$ depends on the soil type. It seems that foliage from shrubs that grow in semiarid regions contains $\mathrm{K}$ as lower levels from costal and this not accordance with [31]. In this study the contents of $\mathrm{Na}$ are lower than those reported in (Abdullah, 2013) study, which it was $(0.48 \mathrm{ppm})$ but they are lower than result found in [32] study (7.95 ppm).

The levels $\mathrm{K}$ and $\mathrm{Cu}$ were significantly decreased in $J$. phoenicea 1 (from polluted area) compared to J. phoenicea 2 (from clean area), while the level of $\mathrm{Ca}$ significantly increased. Rest levels of minerals were found similar in J. phoenicea 1 and $J$. phoenicea 2. In another species level of $\mathrm{Na}, \mathrm{Fe}$ and $\mathrm{Ni}$ were decreased significantly in polluted species $(P$. lentiscus 1) compared to clean species (P.lentiscus 2), while the levels of $\mathrm{K}$ and $\mathrm{Ca}$ was significantly increased in P. lentiscus 1 which collected from polluted area. The results of our study have agreed on the effect of the plant on vegetation with the results of [33]. Chemical qualitative tests for the presence of some secondary metabolites was shown in Table 2. Levels of alkaloids, coumarins, essential oil, flavonoids, glycosides, phenolic compounds, saponins, sterols (triterpens) and tannins were found have similar pattern when compared $J$. phoenicea 1 with P. lentiscus 1 and J. phoenicea 2 with P. lentiscus 2. Both qualitative essential oil and triterpenes were increased in polluted plants $(P$. lentiscus 1 and $J$. phoenicea 1 ). This might be explained by the fact that triterpene compounds and their closely related members occur mainly in the waxy coating of leaves, in fruits such as apples, in resins of barks of trees and in the latex of some plants [34] as a result of presence of construction dust that cause these effective. On other hand qualitative levels of alkaloids, coumarins, flavonoids and phenolic compounds were decreased in polluted plants compared to plants that collected from clean area. Additionally, levels of saponins ware found lower in (P. lentiscus 1 compared to P. lentiscus 2) and (J. phoenicea 1 compared to $J$. phoenicea 2). Distribution of natural products like alkaloids, terpenes and phenolic are well recognized tools for investigating plant population, structures, species and phyletic relationships of genera [35]. Living organisms produce many types of natural products in varying amounts, and quite often the biosynthetic pathways responsible for these compounds differ from one taxonomic group to another. The distribution of these compounds and their biosynthetic pathways correspond well with existing taxonomic arrangements based on more traditional criteria such as morphology. It would concluded that elaboration of principles of chemotaxonomy was carried out in 1816 by De Candolle cited from [30] who pointed out that " plant taxonomy will be the most useful guide to man in his search for new industrial and medicinal plants and that chemical characteristics of plants will be most valuable to plant taxonomy in the future".

Table-1: Mineral element levels in (J. phoenicea 1 and J. phoenicea 2) and (P. lentiscus 1 and P.lentiscus 2) (ppm) (Mean \pm SD)

\begin{tabular}{|l|l|l|l|l|}
\hline Parameter & $\begin{array}{l}\text { J. phoenicea } 1 \\
(\text { mean+SD) }\end{array}$ & J.phoenicea2 (mean+SD) & $\begin{array}{l}\text { P.lentiscus } 1 \\
(\text { mean+_SD) }\end{array}$ & $\begin{array}{l}\text { P.lentiscus } 2 \\
(\text { mean+SD) }\end{array}$ \\
\hline $\mathbf{N a}$ & $6.500 \pm 0.872^{\mathrm{a}}$ & $6.500 \pm 0.872^{\mathrm{a}}$ & $11.220 \pm 1.193^{\mathrm{a}}$ & $6.167 \pm 0.670^{\mathrm{b}}$ \\
\hline $\mathbf{K}$ & $51.607 \pm 1.164^{\mathrm{a}}$ & $24.587 \pm 0.525^{\mathrm{b}}$ & $15.48 \pm 2.19^{\mathrm{a}}$ & $20.677 \pm 0.586^{\mathrm{b}}$ \\
\hline $\mathbf{C a}$ & $60.003 \pm 1.000^{\mathrm{a}}$ & $72.613 \pm 0.567^{\mathrm{b}}$ & $80.780 \pm 0.597^{\mathrm{a}}$ & $85.043 \pm 1.454^{\mathrm{b}}$ \\
\hline $\mathbf{F e}$ & $0.4267 \pm 0.0569^{\mathrm{a}}$ & $0.48667 \pm 0.01528^{\mathrm{a}}$ & $0.5633 \pm 0.0404^{\mathrm{a}}$ & $0.48667 \pm 0.01528^{\mathrm{b}}$ \\
\hline $\mathbf{N i}$ & $2.100 \pm 0.361^{\mathrm{a}}$ & $2.870 \pm 0.324^{\mathrm{a}}$ & $0.23000 \pm 0.01000^{\mathrm{a}}$ & $0.166670 .01528^{\mathrm{b}}$ \\
\hline $\mathbf{C u}$ & $3.000 \pm 0.265^{\mathrm{a}}$ & $1.763 \pm 0.260^{\mathrm{b}}$ & $0.4000 \pm 0.1000^{\mathrm{a}}$ & $5.503 \pm 1.302^{\mathrm{b}}$ \\
\hline
\end{tabular}

Data are expressed as mean \pm SD of 3 replicate. Within each row at same species, means with different superscript (a, b, $\mathrm{c}$ or $\mathrm{d}$ ) were significantly different at $\mathrm{p}<0.05$. Where means superscripts with the same letters mean that there is no significant difference $(\mathrm{p}>0.05)$. 
Table-2: Phytochemical screening of (P. lentiscus 1 and P.lentiscus 2), (J. phoenicea 1 and J. phoenicea 2)

\begin{tabular}{|l|l|l|l|l|}
\hline Components & J.phoenicea 1 & J.phoenicea 2 & P.lentiscus 1 & P.lentiscus 2 \\
\hline Alkaloids & + & ++ & + & ++ \\
\hline Coumarins & + & ++ & + & ++ \\
\hline Essential oil & ++ & + & ++ & + \\
\hline Flavonoids & + & ++ & + & ++ \\
\hline Glycosides & + & + & + & + \\
\hline Phenolic compounds & + & ++ & + & ++ \\
\hline Saponins & + & +++ & + & +++ \\
\hline Sterols and / or triterpenes & ++ & + & ++ & + \\
\hline Tannins & + & + & + & + \\
\hline
\end{tabular}

\section{CONCLUSION}

In conclusion, air pollution was described as an additional stress on plants since they often respond to atmospheric contamination in the same way as they respond to drought and other environment stress. The role of air pollutants causing injury to plants either by direct toxic effect or modifying the host physiology rendering it more susceptible to infection. In severe case of pollution, the injury symptoms were expressed as foliar necrosis or completely disappearance of the plant. In that way the present research work carried out construction dust pollution on morphological and chemical compositions of both speceies, which appeared markedly affected. Al-Jabel Al-Akhdar region, which is rich in plant cover and medicinal plants, is considered as one of the most important areas in the world and, therefore, needs to be announced as a closed protected area by forbidding house constructions in order to save its plant cover and biodiversity.

\section{REFERENCES}

1. Bačić, T., Lynch, A. H., \& Cutler, D. (1999). Reactions to cement factory dust contamination by Pinus halepensis needles. Environmental and Experimental Botany, 41(2), 155-166.

2. Iqbal, M. Z., \& Shafiq, M. (1998). Toxicity of cement dust on the growth of some tree seedlings. Ekologia(Bratislava)/Ecology(Bratislav a), 17(4), 434-439.

3. Mandre, M., Klõšeiko, J., Ots, K., \& Tuulmets, L. (1999). Changes in phytomass and nutrient partitioning in young conifers in extreme alkaline growth conditions. Environmental Pollution, 105(2), 209-220.

4. Mandre, M., \& Ots, K. (1999). Growth and biomass partitioning of 6-year-old spruces under alkaline dust impact. Water, Air, and Soil Pollution, 114(1-2), 13-25.

5. Annuka, E. (1995). Influence of air pollution from the cement industry on plant communities. Dust pollution and forest ecosystems. A study of Conifers in an alkalized environment, 124-133.

6. Nassar, Y., Aissa, K., \& Alsadi, S. (2017). Air Pollution Sources in Libya. Research \& Reviews: Journal of Ecology and Environmental Sciences, 6(1): 62-79.
7. Auzi, A. (1999). Medicinal plants in Libya. In First Conference on Natural Resources", Sert, Libya (in Arabic).

8. El-Taife, A., \& Sherif, A. S. (1986). Flora of Libya: Gymnosperms. al-Faateh univ., Department of botany.

9. Jafri, S. M. H., \& Ali, S. I. (1983). Flora of Libya.

10. Albano, S. M., \& Miguel, M. G. (2011). Biological activities of extracts of plants grown in Portugal. Industrial Crops and Products, 33(2), 338-343.

11. Bakkali, F., Averbeck, S., Averbeck, D., \& Idaomar, M. (2008). Biological effects of essential oils-a review. Food and chemical toxicology, 46(2), 446-475.

12. Drzewiecki, J., Delgado-Licon, E., Haruenkit, R., Pawelzik, E., Martin-Belloso, O., Park, Y. S., ... \& Gorinstein, S. (2003). Identification and differences of total proteins and their soluble fractions in some pseudocereals based on electrophoretic patterns. Journal of agricultural and food chemistry, 51(26), 7798-7804.

13. Ricks, G. R., \& Williams, R. J. H. (1974). Effects of atmospheric pollution on deciduous woodland part 2: effects of particulate matter upon stomatal diffusion resistance in leaves of Quercus petraea (Mattuschka) Leibl. Environmental Pollution (1970), 6(2), 87-109.

14. Peirce, G. J. (1910). An effect of cement dust on orange trees. The Plant World, 13(12), 283-288.

15. Thompson, J. R., Mueller, P. W., Flückiger, W., \& Rutter, A. J. (1984). The effect of dust on photosynthesis and its significance for roadside plants. Environmental Pollution Series A, Ecological and Biological, 34(2), 171-190.

16. Borka, G. (1984). Effect of metalliferous dusts from dressing works on the growth, development, main metabolic processes and yields of winter wheat in situ and under controlled conditions. Environmental Pollution Series A, Ecological and Biological, 35(1), 67-73.

17. Eller, B. M. (1977). Road dust induced increase of leaf temperature. Environmental Pollution (1970), 13(2), 99-107.

18. Eveling, D. W. (1986). Scanning electron microscopy of damage by dust deposits to leaves and petals. Botanical Gazette, 147(2), 159-165. 
19. Eveling, D. W., \& Bataillé, A. (1984). The effect of deposits of small particles on the resistance of leaves and petals to water loss. Environmental Pollution Series A, Ecological and Biological, 36(3), 229-238.

20. Moraes, R., Brown, M., Fuck, R. A., Camargo, M. A., \& Lima, T. M. (2002). Characterization and P$\mathrm{T}$ evolution of melt-bearing ultrahigh-temperature granulites: an example from the Anápolis-Itauçu Complex of the Brasília Fold Belt, Brazil. Journal of Petrology, 43(9), 1673-1705.

21. Barber, J. L., Thomas, G. O., Kerstiens, G., \& Jones, K. C. (2004). Current issues and uncertainties in the measurement and modelling of air-vegetation exchange and within-plant processing of POPs. Environmental pollution, 128(1-2), 99-138.

22. Rawat, J. S., \& Banerjee, S. P. (1996). Urban forestry for improvement of environment. Energy Environment Monitor, 12, 109-116.

23. Tewari, D. (1994). Urban forestry. Indian Forester, 120(8): 647-657.

24. Woo, S. Y., \& Je, S. M. (2006). Photosynthetic rates and antioxidant enzyme activity ofPlatanus occidentalis growing under two levels of air pollution along the streets of Seoul. Journal of Plant Biology, 49(4), 315.

25. El-Khatib, A. A., El-Rahman, A. M., \& Elsheikh, O. M. (2011). Leaf geometric design of urban trees: Potentiality to capture airborne particle pollutants. J. Environ. Stud, 7, 49-59.

26. El-Khatib, A. A., Manal, F., \& Ibrahim, O. M. M. (2007). Removal of airborne particulate pollutants by leaves of urban trees under dry climate of Upper Egypt, an Emphasis on the metalloid leaf deposits. In Inter. Conf. Environ. Protec. Pollut.(18-20), March. Qassim Univ. KSA.

27. Prajapati, S. K., \& Tripathi, B. D. (2008). Biomonitoring seasonal variation of urban air polycyclic aromatic hydrocarbons (PAHs) using
Ficus benghalensis leaves. Environmental Pollution, 151(3), 543-548.

28. Vallès, J., Garcia, S., Hidalgo, O., Martín, J., Pellicer, J., Sanz, M., \& Garnatje, T. (2011). Biology, genome evolution, biotechnological issues and research including applied perspectives in Artemisia (Asteraceae). In Advances in botanical research (Vol. 60, pp. 349-419). Academic Press.

29. Lowry, O. H., Rosebrough, N. J., Farr, A. L., \& Randall, R. J. (1951). Protein measurement with the Folin phenol reagent. Journal of biological chemistry, 193, 265-275.

30. Hegnauer, R. (1967). Chemical characters in plant taxonomy: some possibilities and limitations. Pure and Applied Chemistry, 14(1), 173-188.

31. Queralt, I., Ovejero, M., Carvalho, M. L., Marques, A. F., \& Llabrés, J. M. (2005). Quantitative determination of essential and trace element content of medicinal plants and their infusions by XRF and ICP techniques. X-Ray Spectrometry: An International Journal, 34(3), 213-217.

32. Akrout, A., Mighri, H., Krid, M., Thabet, F., Turki, H., El-Jani, H., \& Neffati, M. (2012). Chemical composition and antioxidant activity of aqueous extracts of some wild medicinal plants in southern Tunisia. International Journal of Life Science and Medical Science, 2(1), 1-4.

33. Jensen, K. F., \& Kozlowski, T. T. (1974). Effect of SO 2 on photosynthesis of quaking aspen and white oak seedlings. In North Amer. For. Biol. Workshop Proc. 3 (Vol. 359).

34. Harborne, A. J. (1998). Phytochemical methods a guide to modern techniques of plant analysis. springer science \& business media.

35. Fairbrothers, D. E., Mabry, T. J., Scogin, R. L., \& Turner, B. L. (1975). The bases of angiosperm phylogeny: chemotaxonomy. Annals of the Missouri Botanical Garden, 765-800. 